Journal of Patient-Centered

8-15-2016

\title{
All the Lonely People
}

John Brill

Follow this and additional works at: https://aah.org/jpcrr

Part of the Bioethics and Medical Ethics Commons, and the Medical Humanities Commons

\section{Recommended Citation}

Brill J. All the lonely people. J Patient Cent Res Rev. 2016;3:153. doi: 10.17294/2330-0698.1255

Published quarterly by Midwest-based health system Advocate Aurora Health and indexed in PubMed Central, the Journal of Patient-Centered Research and Reviews (JPCRR) is an open access, peer-reviewed medical journal focused on disseminating scholarly works devoted to improving patient-centered care practices, health outcomes, and the patient experience. 


\title{
All the Lonely People
}

\author{
John Brill, MD, MPH \\ Undergraduate Medical Education, Aurora Health Care, Milwaukee, WI
}

\author{
All the lonely people, \\ Where do they all come from? \\ All the lonely people, \\ Where do they all belong? \\ -The Beatles, "Eleanor Rigby” (Aug. 5, 1966)
}

The call from the medical examiner's office was all too familiar. "Your patient, D.B., was found dead at home. The landlord checked his apartment after not seeing him for several days and discovered the body. It looks like he was on medicines for diabetes and high blood pressure; anything else? Well, there were no signs of foul play so the examiner plans to get a toxicology panel and sign it out as complications of diabetes. You don't want an autopsy, do you?"

I open the patient's chart to pronounce D.B. as "deceased." Two clicks cancel his overdue diabetes tests and that optimistic colonoscopy referral made many months ago. Noticing his birth date, I reflect that D.B. was younger than he looked; it ages you terribly, social isolation. In fact I will soon be older than him.

"Are you sure you want to close this encounter?" the computer screen asks. I hesitate before sealing his chart for the last time. It feels like I should offer some final service. A memory arises from Catholic funeral rites: "Eternal rest grant unto him, O Lord, and let perpetual light shine upon him."

There will be no other personal closure. I gave up looking for my patients' listings in the obituaries a long time ago. One of the sad truths of our world is

Correspondence: John Brill, MD, MPH, 2801 W. Kinnickinnic River Parkway, \#250, Milwaukee, WI, 53215, T: 414-649-3556,

Email: john.brill@aurora.org that someone has to request and write an obituary, and in the realm of the urban underserved many of our patients do not have anyone to do so. There will be no funeral, no wake, not even a sermon that no one will hear. Many of my patients die this way, unmissed until eventually found dead by a landlord, a social worker, a pastor or the police doing a welfare check - someone whose job it is to care.

It occurs to me that I could write an obituary for D.B., but what would I say? "D.B. went to his eternal reward..." I don't know what his beliefs might have been, what kind of undiscovered realm he foresaw for himself. "Born in..." I know when but not where. "D.B. is survived by..." Who? I think he mentioned a niece once. Looking for his emergency contact, I find someone only identified as "Jim." The number is disconnected.

I realize that I spent D.B.'s infrequent visits trying to motivate him to watch his diet and take his pills; I know his medication doses better than his life story. I knew exactly how poorly his diabetes was controlled but not why or if it mattered to him. Why was he alone, and was he actually lonely? I guess I never asked.

Or perhaps what keeps me from memorializing him is the frightening reflection that we are not so different, D.B. and I. Does it really matter when and where and how we die? A hundred years from now, probably no one will remember much about either of us. We lived, we died. We both had our struggles and, I hope, moments of happiness and joy, where it all made sense. But if only a few paychecks separate each of us from homelessness, how quickly could the slings and arrows of life or our own choices and frailties condemn any one to isolation?

"Are you sure you want to close this encounter?" Yes. More words flicker in, this time from the final salute at military funerals: "Sleep in peace, comrade dear. God is near." 